\title{
Excursions
}

Volume 4, Issue 2 (November 2013) Proceedings: 'Purity'

$11^{\text {th }}-12^{\text {th }}$ July 2013, University of Sussex, Brighton, UK

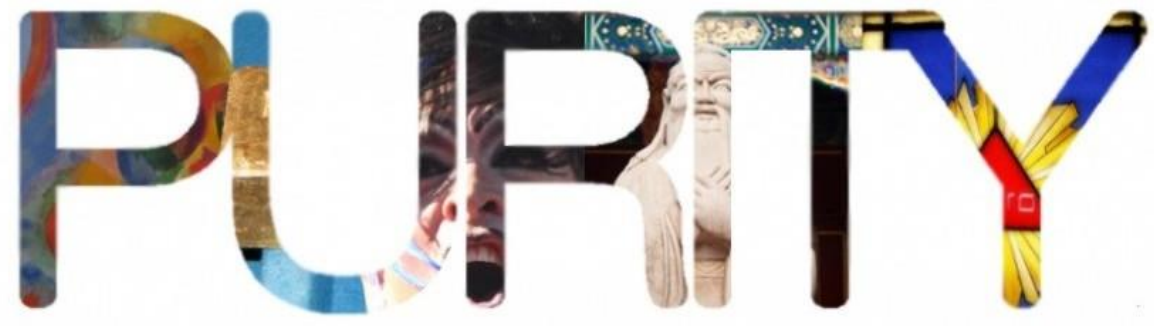

Máire MacNeill, “Dying by the Sword: Manliness, Honour, and Duelling on and off the Stage, 1695-1745"

Excursions, vol. 4, no. 2 (2013) 
Máire MacNeill

Royal Holloway, University of London

\section{Dying by the Sword: Manliness, Honour, and Duelling on and off the Stage, 1695-1745}

The question of how the ideal gentleman ought to behave perplexed society in the early eighteenth century, particularly when the issue of violence arose. Was violence man's prerogative, and an acceptable (indeed, expected) response to a slight against one's family honour? Or was it, as later writers would have it, the case that manly behaviour was exhibited through a refusal to fight and an eagerness to resolve conflict through discussion and mutual understanding? Although there was no clear resolution to this dilemma during the period I am looking at, in this paper I will delve into the debate as it ran during the first half of the eighteenth century and look at the contemporary search for an ideologically pure version of manliness.

The traditional view, that a gentleman's willingness to fight in the name of honour demonstrated his honour, was very old, as Jennifer Low has revealed in Manhood and the Duel (2003), a discussion of sword-fights among gentlemen both on and off the stage in the early modern period. This 
standpoint had a reawakening following Charles II's Restoration in 1660, when scores of his banished allies also returned from the Continent, where they had been living in exile during the Interregnum. With them they brought a collection of fashions and behaviours which influenced wealthy Londoners and came to be associated with the figure of the rake: the gentleman of the Restoration was popularly known for his wit, drinking, whoring, gambling, theatre attendance, and participation in duels to defend his honour. This image was popularised on the stage: rakes or 'sparks' were frequently the heroes of romantic comedies and were shown fighting a rival for the heroine's hand. This is the case in Aphra Behn's The Rover (1677), a comedy about the intrigues and adventures of exiled English cavaliers in Spain. By Act IV, the hero, Belvile, has fallen in love with a Spanish noblewoman, Florinda, but he is indebted to Antonio, who has accepted a challenge from Florinda's brother, Pedro. Antonio has already been wounded from a fight with Belvile's friend, Willmore, so Belvile agrees to disguise himself as Antonio and fight Pedro on his behalf. Belvile wins the fight, disarming Pedro, and he is delighted, saying, 'You've done enough to prove you love Florinda' (IV.ii 49). Belvile's dialogue after this reflects a belief that through his victory, he has a claim to Florinda: 'Touch her not; she's mine by conquest, sir,' he tells Willmore (IV.ii 92), and then, reminding Pedro of his promise, 'You know I ought to claim a victor's right' (IV.ii 100).

Through this series of events, a sword-fight is revealed as a legitimate way of resolving disputes of honour, but they can be undertaken lightly and without long-term consequences. Although Antonio is injured from his swordfight with Willmore, after which Belvile is seized by officers in a case of mistaken identity, Antonio does not die and Belvile is not arrested. Neither they nor any of the other male characters propose that, following these nearmisses, they ought to be less quick to inflame: in fact, Antonio attempts to shoot Willmore later in the play, suggesting that his passions run as high as ever. Although these incidents are deliberately highlighted here in order to draw attention to the thread of violent acts performed in the name of honour throughout the play, the point is not to suggest that the play itself particularly emphasises sword-fighting as the behaviour of a gentleman. Rather, it is striking how little time the characters spend contemplating the place of fighting in their lives. 
The Rover is raucous and patriotic and the English characters are funloving and exciting-as is shown by their quickness to jump into action over romantic affairs-but they are also 'honest' (i.e. royalists) and brave. When Florinda recounts her first meeting with Belvile, she says:

When I was exposed to such dangers as the licensed lust of common soldiers threatened, when rage and conquest flew through the city, then Belvile, this criminal for my sake, threw himself into all dangers to save my honour... (Behn, The Rover, I.i 70-73)

Here, as in the rest of the play, demonstration of moral worth, of patriotism, and of manliness, is configured through the character's willingness to fight and his physical skill at fighting. There is no other special distinction between his past actions as a war hero and his current actions as a libertine in Spain.

I am using The Rover as the principle example of plays of this type due to its popularity, but there were many others during this period that similarly credited the 'private sword' as an aspect of the reasonable behaviour of a gentleman. An earlier play, William Davenant's The Man's the Master of 1673, goes so far as to admit that a challenge to duel is a very serious affair, but the principal scene (IV.iv) is comical. A servant, Jodelet, and his master, Don John, have been disguised as one another for most of the play, and Jodelet receives a challenge from one who believes him to be Don John. Unused to gentlemanly declarations of honour, Jodelet does his best to get out of it: he pretends to misunderstand what he is being asked, then claims that he always thought duels to be very foolish things (The Man's the Master, IV.iv 88-150). Don Ferdinand, who was chosen to deliver the challenge, is very disappointed in these responses: he calls him a coward and asks 'if he has been bred' for this (The Man's the Master, IV.iv 103). This character breaks the news of the challenge with sorrow but his subsequent responses suggest that no matter how sombre it may be to be challenged, it is unthinkable not to accept the challenge. Plays like The Rover and The Man's the Master helped to assert the duel as an activity that demonstrated a man's bravery and honour, and thus proved his manliness.

However, these plays were written at the height of the Restoration period. Duelling was illegal at this time, thanks to a law introduced by Charles II in 1668 , but he was forced to issue a further proclamation against it in 1680 as duelling continued in spite of the law. The problem was that duelling was a 
secret affair, so that the law would likely only find out about it if one of its participants was seriously injured or killed, and Robert Shoemaker (2002, p.537) has pointed out that 'as long as the rules of honour had been followed, those duellists who killed their antagonists were invariably pardoned or convicted of manslaughter and given token punishments'. As it was possible to fight in a duel and receive no real comeuppance, and thanks to the romantic attention assigned to the duellist on the stage, men continued to defend their honour in this way. Yet from the end of the seventeenth century, there are an increasing number of descriptions in literature of honourable gentlemen which emphasise their disinclination to duel and refusal to condone the practice. For example, in the introduction to William Darrell's catechism of 1704, $A$ Gentleman Instructed in the Conduct of a Virtuous and Happy Life, the scholar Eusebius is introduced as a man with aristocratic claims to birth and breeding and who has fought bravely in the service of his country; a man who has honour (both inherited and self-made, or familial and personal) worth defending. Nevertheless, he rejects the challenge to fight in a duel, which is here figured as a popular but superficial form of preserving gentlemanly honour:

Being challenged once to a Duel, he answer'd coldly, Sir, though I fear not your Sword, I tremble at my Maker's Anger; I dare venture my Life in a good Cause, but cannot hazard my Soul in a bad one ... I'll gain Honour by my Disgrace, and shew the World I am no Coward, by daring to censure and obloquy. (Darrell, 1704, pp.17-18) [italics as original]

Honour and valour, certainly admirable virtues in Eusebius's eyes, are here executed in a reversal from the norm: they are demonstrated through deliberate inaction and disinclination to fall in with what he considers fashionable immorality. Such an approach emphasises the roles that rationality and religious fear play in the effecting of these virtues, while implicitly linking dishonour, cowardice, and unwise hazarding of one's personal fate with the duellists who took the easy, fashionable, and socially disruptive route of displaying 'honour'. Darrell's argument thus suggests that in the issue of the duel, gentlemanly honour is inextricably reliant on passivity (which Darrell reveals through forceful independent thought and speech) rather than activity (which is revealed through biddable violence). Robert Shoemaker (2002, p.536) has asserted that an eighteenth-century shift in the 
language associated with duellists caused the 'passive demonstration of "courage" to be celebrated over the 'active assertion of "bravery"' but this surely has its root in the earlier, anti-duelling attempts to suggest honour through the 'daring censure' of Eusebius and other gentlemen of his ilk. Elizabeth Foyster (1999, p.164) makes a similar, more generalised argument when she writes: 'Men should therefore be spirited, but also show that their reason was in control of the actions of their bodies by showing restraint, and by managing anger with decorum'. In Darrell's text, it is Eusebius who is spirited, rather than his challenger; he thus exemplifies the anti-duelling movement's attempts to de-romanticise the duellist by colouring his behaviour as dependent upon the whims of fashion and absent of valour and wisdom.

I put Darrell's work forward here as an example of the new interpretation of gentlemanly honour which was beginning to be championed in the late seventeenth and early eighteenth centuries. This was a more rational and didactic version of honour than the ubiquitous showcasing and gregariousness of the Restoration aristocrat, and the difference between duelling and not duelling was latched onto as a crucial subject in a moral and behavioural overhaul; a gentlemanly display of honour meant shedding his reputation as an unrestrained duellist and emerging as a mannered thinker. Although this re-examination of duelling and duellists was never quite realised as the disruptive social force many longed for it to be, it was nevertheless diligently addressed and debated in sermons, newspaper columns, pamphlets, novels, conduct books, and on the stage. This anti-duelling literature frequently attempted to colour honourable abstention from duelling as an extension of other mounting constituents of gentlemanly behaviour: Anglicanism, Whiggishness, and anti-Jacobitism as well as more imprecise qualities such as politeness and communality. What had been red-blooded self-expression in the early Restoration period was re-imagined by writers like Benjamin Colman in his 1728 pamphlet Death and the Grave without any order as selfish, impulsive, and exhibitionistic, and duelling itself was often associated with antisocial behaviours such as drinking, whoring, gambling, and Sabbathbreaking-as if to discredit duelling by association.

Although some Restoration comedies had shown the dangers of the private sword (as in The Rover, and George Etherege's 1664 piece The Comical Revenge), there was no moral lesson to them. From the end of the seventeenth 
century, however, growing anti-duelling stances were echoed on the stage. In Colley Cibber's Love Makes a Man (1700), the story is centred on two brothers, one bookish, the other foppish and daring, and gauges their experiences with duelling. The play is cautious in being too favourable of either side of the growing duelling debate. When Clodio (the fop) and Carlos (the scholar) realise that they have fallen in love with the same woman, Carlos rejects his former identity and snatches up his uncle's sword:

\begin{abstract}
Car: The first is this-(Snatches D. Lewis's Sword) Win her, and wear her; for on my Soul unless my Body fail, my Mind shall never yield thee up a thought in Love.

Don Lew: Gramercy Charles! To him Boy! I gad! This Love has made a Man of him!

Car: This is the first good Sword, I ever pois'd in Anger yet; 'tis sharp I'm sure, if it but hold my putting home, I shall so hunt your Insolence! -I feel the fire of ten strong Spirits in me. (Cibber, Love Makes A Man, II.i)
\end{abstract}

Much to the surprise of Clodio and the audience, Carlos manages to win the fight, in spite of his inexperience, although Clodio is merely disarmed. From the above, it is Don Lewis's speech that is the most telling: Carlos has attained manhood in his uncle's eyes by filling the role of the Restoration rake, in being ready and willing to fight. His victory over Clodio would seem to further suggest a moral vindication of the fight: in an Aesopic twist, it is the scholarly brother and not the man of the world who wins the fight. It might seem as though Love Makes a Man was thematically of the early Restoration, if not for the events of Acts III and IV. Clodio leaves for Lisbon, where a bravo, Don Duart, picks a fight with him, but Clodio ends up seriously injuring him. For the rest of Act III, both audience and characters believe that Duart has been killed, and Clodio must go into hiding. From the end of the fight until the end of the play, it is clear that fighting is wrong. Of course, being a comedy, the play could hardly end with one of the heroes as a murderer. The fourth act begins with the revelation of Duart's survival, and he is now a changed man.

Don Duart: May I venture yet abroad, Sir?

Surgeon: With safety, Sir; your Wound was never dangerous: though from your great loss of Blood, you seem'd a while without all signs of Life.

Don Duart: Sir, do you know, if the Gentleman that Wounded me be in Custody.

Surgeon: He was never taken, Sir, nor known, that I cou'd hear of. 
Don Duart: I am sorry for't; for cou'd I find him, which now shall be my earnest care, I wou'd with real Services acknowledge him my best of Friends, in having prov'd so fortunate an Enemy: he has bestow'd on me a second Life, which from a clearer insight of my self, will teach me now to use it better too. (Cibber, Love Makes A Man, IV.i 1-12)

This 'clearer insight' is essentially the rationality of the new English hero, and Duart's progress across the second half of the play represents the evolution from the blackest libertine to the most refined, domesticated gentleman. His change of heart is the final word on sword-fighting in the play. This plotthread shows the danger of sword-fighting: blood may be shed, men may die, and the victor must go into hiding. Duart's speech is the natural outcome of all of these possibilities, and given that sword-fights play no further part in the play, we can assume that the audience was meant to take this new moral lesson at face value. However, the moral for Clodio is entirely different from the one given to his brother Carlos. Sword-fighting has two, opposite representations in the play-one as an essential stage in attaining manliness, and another as a foolish and outrageous activity that can end with death and imprisonmentand both seem equally rational. What, then, are we to take away from these two conflicting portrayals of sword-fighting? Placed side by side, they represent Cibber's attempt at a compromise between the two opposing parties. The two sword-fights are not entirely equal: the fight between Carlos and Clodio stems from honour and the intention of righting a wrong, while Duart's attack on Clodio is shown to be random: 'No Man living shall command me', he declares to his family (III.i 15-16). The advice his uncle, the Governor of Lisbon, gives him, seems to be the closest resemblance to authorial comment breaking through into the play:

\footnotetext{
You are too boisterous Sir, and this vain Opinion of your Courage, taken on your late Success in Duelling, makes you daily shun'd by Men of civil Conversation; for shame leave off these senseless Brawls; if you are Valiant, as you wou'd be thought, turn out your Courage to the Wars, let your King and Country be the better for't. (Cibber, Love Makes A Man, III.i 9-14)
}

The recommendation for 'too boisterous' young men to exert their need to fight by joining the army is one that tallies with popular opinion, although it ignores the aforementioned tendency for officers to involve themselves in duels. In a play deeply concerned with the emotional development of young 
men, romantic love is, in spite of the title's implication, only responsible for the advance into maturity for Carlos and possibly Clodio (the ending is ambiguous as to how much emotional progress he has actually made); Duart's entire redemption comes from his rejection of fighting following his brush with death. By actually depicting the physical dangers of the duel to their audiences, comedies like Love Makes a Man can be read as part of the developing cultural awareness of duelling as a hazardous occupation-an observation that had until then been more applicable to the arena of tragedy.

These new comedies managed to both allow audiences to enjoy the spectacle of the duel as entertainment and then recant what it had shown with the moral lesson that duelling was a foolish and dangerous endeavour. Duelling might be the common activity of most men, but men of 'civil conversation', those who had pretensions to moral worth and higher understanding, shunned it. These initial attempts to disintegrate the duel were a crucial part of efforts to create rational gentlemen who preferred the pleasures of domesticity, in contrast to the sensual excesses which were consistently associated with the duellist. These reached their peak in Richard Steele's 1722 comedy The Conscious Lovers, which incorporates a failed duel. Here, the duel is a matter of serious concern-the hero, Young Bevil, doesn't take the challenge lightly, nor does he express cowardice-but the dilemma is brief and happily resolved. His rationality stands him in stark contrast to the heroic adventures of his father, which are spoken of affectionately'challenging and fighting, scaling walls-locking up the lady-and the gallant under an arrest for fear of killing all his rivals' (The Conscious Lovers, I.ii 6366)-but also with detached amusement. This flippant speech characterises his father's youthful exploits as a series of dramatic absurdities, adventures that Bevil would never have, nor show any interest in having.

The problem with these newer heroes was the same setback that Cibber was trying to avoid in his earlier plays, and Love Makes a Man especially showcases the struggle between the old ideology and the new. Although Duart's persistent belligerence is nearly disastrous for him and Clodio, the only way for Carlos to break out of his role as a scholar and become a lover is to fight. Compared to the exciting Restoration rake, a red-blooded lover and fighter, new heroes like Young Bevil seemed pale and boring. There was also 
an underlying anxiety that, because fighting had been so firmly fixed in the public imagination as manly behaviour, heroes who spoke against fighting could seem cowardly and unmanly. The body of the new English hero thus had to stand in contrast to the affected mannerisms of the fop-who was mannerly and usually non-violent in spite of carrying a fashionable sword, but also frivolous and effeminate-but could not be ruled by the impulses of the heroic hero-who was muscular and brave but also rash and belligerent. Both types also carried with them associations with Catholicism and foreignness; both were also construed as antisocial and showcasing. In realising the potential to politicise the male body, the early eighteenth century thus saw conduct books examine the most gentlemanly ways to walk, sit, gesticulate, dance, and fence, and Paul Goring (2004, p.116) has argued that actors of this time were used as 'a means of emblematising polite society and of showcasing modes of polite self-representation'.

The obvious anxiety writers felt in forming their stage heroes - not wanting to make them too transparent or too soft-reflects a desire to present a clear and consistent value system to their audience. In doing so, they had to redefine what was meant by honourable behaviour. Criticism levelled at duellists emphasised that their conduct was 'impolite' and 'not gentlemanlike', and instead acted on impulse and drew attention to themselves. As such, it is noticeable that duelling-an activity that had always been regarded as a surreptitious and private affair (in reality, if not always on stage) between two duellists and two seconds-was drawn into the public gaze to become a vicedriven communal activity, at best associated with public misbehaviour and at worst on a par with drinking and whoring. There is an emphasis on an expected level of purity of thought and deed and Cibber (along with Steele, Addison, Farquhar, and Centlivre) strove to provide consistency between the behaviour of their protagonists. Duelling was now looked upon blackly by reformers of the stage, so now a good man could not be presented as a duellist; his honour had to be shown through demonstrations of fidelity and filial obedience.

Through the commentators I have discussed, we may observe a rejection of the seventeenth-century assertion of selfhood: true expression of the self was now to detach it from what the priest Edward Lovell (1716, p.13) described as 'the softest Inclinations of our Nature'-that is, the desires of the body-and 
replace them with behaviour founded in spirituality and intellectual thought and reason. The configuration of the body as a weak instrument that needed the mind to lift and purify it through temperance, reason, and obedience, is a common theme throughout literature of this period. It was the responsibility of gentlemen now to settle down and become dutiful fathers, lawful statesmen, and good Christians, ignoring their 'base' desires that drew them towards fighting and womanising; a form of ordained rebirth for the theatrical hero which would resonate across the rest of the eighteenth century. 


\section{Bibliography}

Behn, A., 1677. The Rover. [manuscript] Oxford: Bodleian Library.

Cibber, C., 1701. Love Makes a Man. [manuscript] London: British Library.

Colman, B., 1728. Death and the Grave Without Any Order. [manuscript] London: British Library.

Darrell, W., 1704. A Gentleman Instructed in the Conduct of a Virtuous and Happy Life. [manuscript] London: British Library.

Davenant, W., 1673. The Man's the Master. [manuscript] London: British Library.

Foyster, E., 1999. Boys Will Be Boys? Manhood and Aggression 1660-1800. In: T. Hitchcock and M. Cohen, 1999. English Masculinities, 1660-18oo. London: Longman. pp.151-166.

Goring, P., 2004. The Rhetoric of Sensibility in Eighteenth-Century Culture. Cambridge: Cambridge University Press.

Low, J, 2003. Manhood and the Duel: Masculinity in Early Modern Drama and Culture. New York: Palgrave Macmillan.

Lovell, E, 1716. Justice and mercy equal supporters of the throne. [manuscript] London: British Library.

Shoemaker, R.B., 2002. The Taming of the Duel: Masculinity, Honour and Ritual Violence in London, 1660-180o. The Historical Journal, 45(3). Available through: JSTOR [Accessed 30 May 2013].

Steele, R, 1722. The Conscious Lovers. [manuscript] London: British Library. 